\title{
France plans national gene therapy strategy
}

Paris. France's ministries of health and of research have announced their intention to coordinate their support for genome research and its clinical applications under the umbrella of a single so-called 'Génome-Santé' programme.

The initial goals of the joint programme, which will also involve medical charities such as the influential French Muscular Dystrophy Association (AFM), will include strengthening fundamental research in gene therapy, creating gene therapy centres at major hospitals, and increasing the emphasis on genetics in medical training.

The new integrated approach has been welcomed by both medical charities and researchers in gene therapy. "It's a radical change of government attitude," says Bernard Barataud, the president of the AFM, which has been a driving force in French genome efforts, and which created the Généthon laboratory in 1990 with the Paris-based Centre d'Etudes du Polymorphisme Humain (CEPH). Barataud, who has long criticized genome efforts in France as being too fragmented, says there is now the beginning of "a vision of the whole".

The most immediate measure is a call for research proposals in gene therapy, to be funded jointly by the two ministries, the National Agency for AIDS Research, AFM and the National League Against Cancer. This will provide around FFr35 million (US\$6.6 million) in 1995, and aim, in particular, to support the creation of a handful of gene therapy centres associated with major hospitals.

Priorities will include fundamental research on animal models of genetic diseases and on new vectors. This shows that the government accepts that progress depends on easing bottlenecks in fundamental research, says Alain Fisher, who leads France's largest gene therapy group at the Hôpital Necker in Paris.

Fisher, who was a co-author of a recent report to the government on gene therapy, also says he is pleased that the joint call for proposals will be peer reviewed by a committee that includes foreign scientists.

Under the plans, France's 43 medical schools would also create new staff positions for teaching new genetics courses. Only 15 schools have well developed genetics programmes, says François Fillon, the science minister, who also intends to create a new specialized diploma in genome studies.

As expected, the government has also decided to simplify regulatory procedures for gene therapy. In particular, a single interministerial commission will take over the work of the existing labyrinth of regulatory committees (see Nature 371, 550; 1994).

Another committee will be created to regulate DNA and gene banks, and oversee the contractual arrangements for their eventual commercial exploitation. This follows the public row earlier this year over a proposal that would have given Millennium, a Massachusetts-based biotechnology company, access to a DNA bank at CEPH in Paris (see Nature 370, 4; 1994).

\section{IMAGE UNAVAILABLE FOR COPYRIGHT REASONS}

\section{énéthon's gene library will be key element.}

But enthusiasm for the government's proposals for gene therapy has been tempered by wider concerns. One is that, although the government is already setting up a national committee to 'coordinate' life sciences research among the various research bodies, with genome research a

\section{UK 'should abandon quarantine law'}

London. The United Kingdom's strict quarantine laws should be immediately replaced with a system of vaccination and bloodtesting for pet cats and dogs, according to a report published last week by the Agriculture Committee of the House of Commons.

The committee says that scientific advances made since the last review of the laws in 1971, such as the development of safe vaccines and accurate serological tests, mean that it is "not only feasible but desirable" for the United Kingdom to adopt a scheme similar to those already operated in mainland Europe, and introduced by Norway and Sweden in May.

But the recommendations received a cool reception from William Waldegrave, the agriculture minister. He said he would look carefully at the recommendations, but he emphasized that alternatives would have to be shown to offer at least as much protection as the present system.

Veterinary groups were equally cautious, arguing that replacing quarantine rules immediately would be premature. "It's the cost and the anxiety and the worry of living with rabies that we want to avoid," says Neal King, president of the Royal College of Veterinary Surgeons.

Under the recommendations, six months' quarantine would still apply to cats or dogs coming from non-approved countries. But declared priority, budgetary pressure may undermine France's commitment to maintaining a strong research base in life sciences in the research organizations.

Some scientists point out, for example, that the life sciences budget (excluding salaries) of the Centre National de la Recherche Scientifique (CNRS), France's principal research organization, has fallen by more than 14 per cent in less than two years. Funding for the biomedical research organization INSERM is also decreasing.

Furthermore, concern that research organizations may lose control over scientific choices to those more interested in shortterm results is being stimulated by the growing influence of medical charities, whose resources now exceed the FFr900 million a year that the government spends on genome research.

Fisher claims there is a potential risk that the state will abandon its responsibilities to support long-term research, and that the presence of charities may lead to too much emphasis on applied research aimed at shortterm goals. Moreover, although some charities - including AFM - operate rigorous peer-review systems, he is concerned that others may distribute their money unwisely.

Declan Butler

others would avoid quarantine if they had been vaccinated with an approved inactivated rabies vaccine, had lived in an approved country for at least six months, were identified by tattooing or microchipping, and had a blood test showing rabies immunity four months after vaccination.

But the Royal College of Veterinary Surgeons and the British Veterinary Association (BVA) argue that Britain lacks the necessary infrastructure to police such a system adequately. Every point of entry into the United Kingdom would have to have a special animal channel, as well as facilities to carry out an animal health check.

They are also worried about adequate identification and certification: tattoos can be tampered with or the same number can be used on different animals, and microchip systems would have to be compatible for all approved countries. Paul DeVile, president of the BVA, also says that he is worried about the authenticity of certification.

"Certainly the advances over the last few years have been quite remarkable, both with the efficacy of vaccines and as regards the oral vaccination of foxes," says DeVile. But he added that he would like to see rabies eliminated from the European Union before quarantine restrictions were relaxed.

Maggie Verrall 